\title{
Botany
}

\section{Chronic deer browsing leads to biotic homogenization of minerotrophic peatlands}

\begin{tabular}{|c|c|}
\hline Journal: & Botany \\
\hline Manuscript ID & cjb-2017-0145.R1 \\
\hline Manuscript Type: & Article \\
\hline Date Submitted by the Author: & 27-Mar-2018 \\
\hline Complete List of Authors: & $\begin{array}{l}\text { Courchesne, Milène; Universite Laval Faculte des sciences de l'agriculture } \\
\text { et de I'alimentation } \\
\text { Pellerin, Stéphanie; Université de Montréal } \\
\text { Bachand, Marianne; Universite Laval Faculte des sciences de l'agriculture et } \\
\text { de I'alimentation } \\
\text { Côté, Steeve; Laval University } \\
\text { Poulin, Monique; Universite Laval Faculte des sciences de l'agriculture et de } \\
\text { l'alimentation, Phytologie }\end{array}$ \\
\hline Keyword: & bogs, fens, herbivory, vegetation change, deer exclusion \\
\hline $\begin{array}{r}\text { Is the invited manuscript for } \\
\text { consideration in a Special } \\
\text { Issue? : }\end{array}$ & N/A \\
\hline
\end{tabular}




\section{Chronic deer browsing leads to biotic homogenization of minerotrophic} peatlands

Milène Courchesne ${ }^{1,2}$, Stéphanie Pellerin ${ }^{1,2,3}$, Marianne Bachand ${ }^{1,2,3}$, Steeve D.

Côté $^{1,2,4}$ and Monique Poulin ${ }^{1,2, *}$.

*Corresponding author: Phone: 1-418-656-2131 ext. 13035,

email: monique.poulin@fsaa.ulaval.ca

${ }^{1}$ Chaire de recherche industrielle du CRSNG en aménagement intégré des ressources de l'île d'Anticosti, Département de biologie, 1045 ave. de la Médecine, Université Laval, Québec, Qc, Canada, G1V 0A6

${ }^{2}$ Québec Centre for Biodiversity Science, McGill University, 191205 Dr. Penfield Avenue, Montreal, Qc, Canada, H3A 1B1

${ }^{3}$ Institut de recherche en biologie végétale, Jardin Botanique de Montréal and Université de Montréal, 4101 Sherbrooke Est, Montreal, Qc, Canada, H1X 2B2

${ }^{4}$ Centre d'études nordiques, Université Laval, 2405 rue de la Terrasse, Québec, Qc, Canada, G1V 0A6 
1 Abstract: Peatlands could become important foraging habitats, and their plant

2 communities threatened, in areas with an overabundance of large herbivores. Peatland

3 response to herbivore exclusion may vary widely according to abiotic conditions and

4 associated species, due to a strong minerotrophic gradient. We assessed the impact of

5 white-tailed deer (Odocoileus virginianus Zimm.) on peatland vegetation using an

6 exclosure experiment. A total of 53 pairs of exclosures and unprotected plots were set up in

7 bogs (13 pairs), sedge fens (20), shrub fens (7) and laggs (13), and surveyed prior to

8 exclosure construction as well as three, five and eight years after. Vascular plant

9 composition of exclosures diverged from that of unprotected plots through time only in

10 shrub fens and laggs. Bryophytes remained constant in all habitats. On average, shrub cover

11 was 30\% higher in exclosures in all habitats after five years, while herb cover increased

12 only in laggs, by $43 \%$, after eight years. Reclassification of sites by $\mathrm{pH}$ showed deer

13 exclusion promoted alpha diversity in low- and high-moderate rich fens (pH 5.3-6.8) and

14 beta diversity in the latter as well as in rich fens ( $\mathrm{pH}$ 6.3-7.5). Overall, our results suggest

15 that conservation efforts in areas with overabundant large herbivores should target richer

16 peatland habitats since they showed a higher resilience and fostered alpha and beta

17 diversity.

18 Key words: bogs, fens, herbivory, laggs, vegetation change, deer exclusion

19 Résumé : Les tourbières pourraient représenter des habitats importants pour les grands

20 herbivores dans des conditions de surpopulation, ce qui pourrait affecter leur végétation.

21 Caractérisées par un fort gradient de minérotrophie, la réponse des tourbières suivant

22 l'exclusion des herbivores peut varier grandement selon leurs conditions abiotiques et les 
23 espèces associées. Nous avons évalué l'impact du cerf de Virginie (Odocoileus virginianus

24 Zimm.) sur la végétation des tourbières à l'aide d'un dispositif d'exclos. Cinquante-trois

25 exclos appariés à des parcelles non-protégées du broutement ont été échantillonnées dans

26 des bogs (13), des fens à Carex (20), des fens arbustifs (7) et des laggs (13) avant, ainsi que

27 trois, cinq et huit ans après l'instauration des exclos. Avec le temps, la composition des

28 plantes vasculaires dans les exclos divergeait de celle des parcelles non-protégées

29 seulement pour les fens arbustifs et les laggs. Le couvert des bryophytes est resté stable

30 dans tous les habitats. Le couvert des arbustes était $30 \%$ plus important dans les exclos

31 (tout habitat confondu) après cinq ans alors que le couvert des herbacées était de $43 \%$ plus

32 élevé après 8 ans. Les sites ont été reclassifiés selon leur pH pour tester l'effet de

33 l'exclusion du cerf le long du gradient minérotrophique. L'exclusion du cerf a engendré une

34 plus grande diversité alpha dans les fens intermédiaires ( $\mathrm{pH}$ 6.3-6.8) et une plus grande

35 diversité beta dans les fens intermédiaires et riches ( $\mathrm{pH}$ 6.3-7.5). Globalement, nos résultats

36 suggèrent que les efforts de conservation dans les régions à fortes densités de cerfs

37 devraient cibler les tourbières riches puisqu'elles ont montré une plus grande résilience et

38 une diversité végétale locale et régionale accrue suivant l'arrêt du broutement.

39 Mots-clés: bogs, fens, herbivorie, laggs, changements floristique, cerf de Virginie 
41

42

43

44

45

46

47

48

49

50

51

52

53

54

55

56

57

58

59

60

61

62

63

\section{Introduction}

In recent decades, many large herbivore populations have increased substantially worldwide, inducing tremendous changes in native ecosystems (Côté et al. 2004). The impacts of overabundant herbivores on forests and grasslands have been studied widely, and include altered plant composition and diversity due to reduced abundance and biomass of preferred species, and increased cover of browsing-tolerant or resistant species (e.g., Rooney and Waller 2003; Tremblay et al. 2007; Mayer et al. 2009; Beguin et al. 2011; Goetsch et al. 2011; Waller 2014). The impacts of large herbivores on peatlands are much less understood. Yet, for wild ungulates, peatlands may represent significant alternative habitats for foraging activities, especially in temperate and boreal regions of North America where populations are overabundant (Massé and Côté 2009) and peatlands widespread.

Most studies on the impacts of large herbivores on peatlands have focused on grazing domestic herbivores (Rawes and Hobbs 1979; Rawes 1983; Ausden et al. 2005). The longterm impacts of grazing and trampling by sheep and cattle in peatlands depend on several factors, such as season of use and management history (Smith et al. 2003), but in general include a reduction in cover and richness of bryophytes (Arnesen 1999; Stammel and Kiehl 2004) and in total vegetation biomass (Ausden et al. 2005), while stoloniferous grasses, sedges and rosette forbs increase in abundance and biomass (Rawes and Hobbs 1979; Rawes 1983; Birnie and Hulme 1990; Ward et al. 2007). Fewer studies have investigated the impact of browsers (but see Johnson and Leopold 1998; Pellerin et al. 2006), a type of herbivore with broad diet niches, specialized in digesting woody plants (Hofmann 1989). In that regard, the specific study by Pellerin et al. (2006) showed that white-tailed deer (Odocoileus virginianus), a selective browser, changed plant species composition of 
64 minerotrophic peatlands (fens), but not ombrotrophic ones (bogs), although the latter had a 65 reduced lichen cover and an increased sedge and grass cover when deer were present. 66 Unbrowsed fens also had higher species richness, especially for shrubs and sedges.

67 Aside from the variation associated with herbivore species, the impact of herbivores on 68 peatlands could vary in relation to local abiotic conditions and plant traits. Peatlands are 69 characterized by a strong minerotrophic gradient, from bogs to extreme-rich fens 70 (Szumigalski and Bayley 1996), along which plant composition and production vary 71 strongly. Herb production or net productivity generally increase along the minerotrophic 72 gradient while decreasing for shrubs (Szumigalski and Bayley 1996; Thormann and Bayley 73 1997; Moore et al. 2002). The rate of nutrient cycling and N/C ratio in plant tissue increase 74 with minerotrophy, and plants in rich fens should have lower constitutive defences against 75 herbivores since such strategies are fostered in poorer environments (Bryant et al. 1983; 76 Koricheva et al. 1998). These factors combined could promote higher herbivory in fens 77 than in bogs (Mattson 1980). On the other hand, fens could have a higher ability to recover 78 from herbivory than bogs because of higher nutrient availability (Maschinski and Whitham 79 1989; Wise and Abrahamson 2005). In addition, minerotrophic ecotones between open 80 peatland expanses and adjacent mesic forests, commonly called laggs (Howie and Tromp81 van Meerveld 2011), often have a thinner peat deposit than bogs (Paradis et al. 2015). This 82 should facilitate plant recovery after aerial biomass browsing because roots and rhizomes 83 left in place have more direct access to nutrients in the underlying mineral soil. Fens also 84 show a higher abundance of graminoid plants, which are known to have a strong capacity 85 for compensatory growth through basal intercalary meristems (Haukioja and Koricheva 86 2000). Fens could thus be more resistant or resilient to browsing compared to bogs, but to 
87 our knowledge, no studies have evaluated variation in herbivory or recovery abilities after

88 herbivore control or exclusion along a minerotrophic peatland gradient.

89 Species richness also varies along the minerotrophic gradient in peatlands and may

90 influence the response of bogs and fens to browser exclusion as ecosystem resilience is

91 thought to be greater within species rich communities (Peterson et al. 1998; Folke et al.

92 2004; Downing et al. 2012). The few studies that have investigated species diversity over

93 the bog-rich fen gradient point toward either a unimodal response with greater diversity in

94 intermediate to rich fens (Johnson and Leopold 1994; Locky and Bayley 2006), higher

95 diversity in extremely rich fens (Vitt et al. 1995) or, more widely, toward higher diversity

96 in fens compared to bogs (Wheeler 1993; Warner and Asada 2006). Yet, these studies

97 focused mostly on site diversity (alpha-diversity), whereas peatland beta diversity remains

98 basically unexplored. Beta diversity refers to the variation of species composition among

99 sites, and is now recognized as an important component of evaluations of biodiversity loss

100 as well as conservation and management planning (Gering et al. 2003). Overabundant large

101 herbivore populations have been shown to foster biotic homogenization (i.e., an increase in

102 the similarity of communities across space and time) of ground and sapling layers in forests

103 or shrublands (Rooney et al. 2004; Rooney 2009; Schumacher and Carson 2013; Perea et

104 al. 2014), and in meta-communities including grasslands and forests (Ohashi and Hoshino

105 2014), but their impacts on diversity can vary along abiotic gradients (Austrheim and

106 Eriksson 2001; Bakker et al. 2006; Speed et al. 2013). In grasslands, large herbivores have

107 been shown to increase plant diversity on sites with high productivity, but to decrease

108 diversity on sites with low productivity (Bakker et al. 2006). Because biotic

109 homogenization is considered an important cause of global diversity loss (McKinney and

110 Lockwood 1999) and is associated with decreased ecosystem stability and resilience (Olden 
111 et al. 2004), the impact of herbivores on the homogenization process is of great interest, 112 notably under variable environmental conditions.

113 The presence of white-tailed deer at high density on Anticosti Island for several decades, 114 the abundance of peatlands and the absence of human disturbance on these wetlands 115 provide a unique opportunity to evaluate the response of peatlands to herbivore exclusion. 116 We set up a deer exclosure experiment in four habitat types (bogs, sedge fens, shrub fens 117 and laggs) and assessed the response of vegetation over eight years. More specifically, we 118 hypothesized that the response of peatlands to deer exclusion would be intimately 119 associated with the minerotrophy of such habitats. Specifically, we predicted that, after deer 120 exclusion, plant communities would diverge from browsed communities in minerotrophic 121 habitats (fens and laggs), but not in nutrient-poor bogs, either because of the greater 122 attractiveness of fens and laggs for deer, compared to bogs, or because of a higher recovery 123 rate in rich habitats. In addition, we expected that herbs and shrubs would be favored by 124 deer exclusion, with the former responding more strongly at high $\mathrm{pH}$ and the latter at low 125 pH. Finally, we expected that beta diversity would be greater under deer exclusion than on 126 browsed sites, this difference increasing with peatland minerotrophy, since browsing is 127 likely to intensify on more minerotrophic sites.

\section{Methods}

129 Study area

130 Our study was carried out on Anticosti Island $\left(7943 \mathrm{~km}^{2}\right)$, located in the Gulf of 131 St. Lawrence in Quebec, Canada $\left(49^{\circ} 28^{\prime} \mathrm{N} ; 63^{\circ} 00^{\prime} \mathrm{W}\right)$. The climate is maritime and 132 generally humid, with total annual precipitation of $917 \pm 130 \mathrm{~mm}$ (mean \pm standard 133 deviation) and a mean temperature varying from a minimum of about $-12^{\circ} \mathrm{C}$ in February to 134 a maximum of about $16^{\circ} \mathrm{C}$ in July (Environment Canada 2006). The island's present-day 
135 forests belong to the eastern Abies balsamea (L.) Mill.-Betula papyrifera Marshall

136 bioclimatic subdomain (Saucier et al. 2009). The original forests were composed of $A$.

137 balsamea, Picea mariana (Mill.) B.S.P., Picea glauca (Moench) Voss and deciduous

138 species such as B. papyrifera (Lavoie and Fillion 2001). Approximately 220 white-tailed

139 deer were introduced on Anticosti Island at the end of the $19^{\text {th }}$ century, and proliferated

140 rapidly in the absence of predators. Today, the deer population reaches a density $>20$ deer

141 per square kilometre and up to 56 deer per square kilometre locally (Tremblay et al. 2007).

142 Chronic deer browsing has drastically modified forest composition by causing the quasi-

143 disappearance of the shrub layer and most deciduous species, and compromising the

144 regeneration of Abies balsamea, which are being gradually replaced by Picea glauca

145 (Potvin et al. 2003; Barrette et al. 2010).

146 Large bogs and fens are common in wet depressions, covering about $25 \%$ of the island

147 (Massé and Côté 2009). Since these peatlands have never been exploited or drained, the

148 effects of browsing on them could not be confounded with anthropogenic disturbances.

149 Peatlands selected for the study are located in the western part of the island, where deer

150 density varies between 19 and 24 deer per square kilometre (Rochette and Gingras 2007).

151 We selected four types of habitat that are common on the island: bogs, sedge fens, shrub

152 fens and laggs. Habitats were segregated according to their general vegetation composition.

153 Bogs are dominated by Sphagnum mosses and ericaceous shrubs, fens by sedges, herbs and

154 brown mosses. Tall trees were virtually absent from bogs and fens. We further

155 differentiated between sedge and shrub fens according to a threshold of $25 \%$ of shrub

156 cover. Laggs are the transition zone between an ombrotrophic bog and the mineral soils of

157 the surrounding landscape. When they are present, they are usually characterized by high

158 water level and nutrient availability, shallow peat of relatively low hydraulic conductivity 
159

160

161

162 163

and unique ecotonal species (Howie and Tromp-van Meerveld 2011; Paradis et al. 2015). They are recognized as minerotrophic and dominated by fen vegetation, usually with dense shrub and tree covers. On Anticosti Island, laggs are dominated by graminoids, sedges, deciduous shrubs and coniferous trees such as P. mariana and Larix laricina Du Roi K. Koch. In a previous study, it was found that deer use laggs for movements and foraging activities three times more than bogs and two times more than fens (Massé and Côté 2009).

Experimental design and sampling

In 2007, $4 \mathrm{~m}^{2}$ exclosures were established in 13 bogs, 20 sedge fens, 7 shrub fens and 13 laggs. Each exclosure was paired with a similar area in close proximity (ca. $5 \mathrm{~m}$ ) within the same peatland and used as a control browsed plot (hereafter, unprotected plot) representing in-situ deer density. Overall, there were a total of 106 plots distributed by pairs on 53 sites. When staking out plots, trees and saplings were avoided due to their height compared to the small $(2 \times 2 \mathrm{~m})$, low $(1.22 \mathrm{~m})$ dimensions of exclosures. Deer tracks were also avoided so as not to confuse the effect of browsing with that of trampling. The mesh size of the fences was small enough (1.5 inch) to prevent snowshoe hare (Lepus americanus) intrusion.

Vegetation was sampled in July 2007 (prior to exclosure construction), 2010, 2012 and 2015 in a $1 \mathrm{~m}^{2}$ plot centered within each exclosure and unprotected plot. The cover of all plant species was estimated to the nearest $1 \%$ between $0-10 \%$ and $90-100 \%$, otherwise to the nearest 5\%. In 2015, the height of the most abundant herbaceous species was measured (3 individuals of each species in each plot). The presence of any flower or fruit was also noted. Surface water $\mathrm{pH}$ was also assessed in 2015 using a portable handheld probe (HI98129 pH/Conductivity/TDS Tester, Hannah Instruments, Model \#98129) at a single location between paired plots. 
182

183

184

185

186

187

188

189

190

191

192

193

194

195

196

197

198

199

200

201

202

203

204

205

Data analyses

\section{Changes in vegetation composition over time}

We used Principal Response Curves (PRC) to describe the temporal shifts in vegetation composition in response to browsing cessation (Van den Brink and Ter Braak 1999). PRC is a type of partial redundancy analysis that represent a response (vegetation composition) of a given treatment (exclosures) as a deviation from a comparison benchmark (unprotected plots) along a time axis. An independent PRC was performed for each habitat, with vascular plants and bryophytes analysed separately. To account for the double-absence of species, a Hellinger transformation was applied to species cover data (Legendre and Gallagher 2001). To consider the paired structure of the design, we first conducted an analysis of variance (ANOVA) on the cover of each species using pairs as random factor and then used the residuals to run the PRC. In complement to the PRC, we compared the change in plant composition between exclosures and unprotected plots for each year after the set-up of the experiment using a linear mixed model. For this analysis, site scores along the first axis of the PRC were used as response variables, and treatment and time elapsed since the beginning of deer exclusion as explanatory variables. Normality and homogeneity of variance assumptions were verified and a model with heterogeneous variances for the

year was used when necessary (shrub fens and laggs). Spatial (site) and temporal (year) correlation, including time nested within the spatial variables (repeated measures), were used as random factors (Alday and Marrs 2014). A Bonferroni correction was applied to account for multiple year comparisons (four years; $\alpha=0.0125$; Sokal and Rohlf 1995).

Vegetation structure

Cover of shrubs, herbs and bryophytes was estimated by summing the cover of all species for each stratum for each site. The effects of deer exclusion on cover as well as on 
206 herb height were evaluated by repeated measures ANOVA (Supplementary data, Table S1).

207 When the interaction between deer browsing and type of habitat or time was significant, a 208 Protected Fisher's Least Significant Difference (LSD) test was performed to compare 209 values among the habitats or among years. Cover of all vegetation types was log210 transformed to comply with the normality assumption of the parametric tests, and a model 211 with heterogeneous variances for the types of habitats was used when necessary (shrub 212 fens).

213 Minerotrophic gradient and alpha and beta diversity

214 Because beta diversity involved comparisons between groups of sites, the exclosures 215 (53) and unprotected plots (53) were reclassified into four groups using a k-means non216 hierarchical partitioning analysis of $\mathrm{pH}$ values. The $\mathrm{pH}$ of the surface water of the first 217 group ranges between 2.8 and 4.2 (bogs: 13 sites), between 5.3 and 6.2 for the second (low 218 moderate rich fens: 6 sites), between 6.3 and 6.8 for the third (high moderate rich fens: 23 219 sites) and between 6.9 and 7.5 for the fourth group (rich fens: 11 sites; Zoltai and Vitt 220 1995). These four groups were then used to evaluate whether deer browsing reduced plant 221 alpha and beta diversity in peatlands and whether this process was related to site 222 minerotrophy. Only 2015 data on vascular species was used for this analysis.

223 For each $\mathrm{pH}$-based site group, we calculated both the species richness (S) and Shannon 224 index (H'; Shannon and Weaver 1963). Differences in beta diversity along the 225 minerotrophic gradient and between deer browsing levels were analysed using tests of 226 homogeneity for multivariate dispersions (Anderson et al. 2006). A site-by-site distance 227 matrix was first used to compute the centroid of each group of sites (eight groups: four 228 minerotrophic levels and two deer browsing levels). The distance of each site (plot) to its 229 associated group centroid was then calculated. The site-by-site distance matrices required 
230 for this test were computed with the percentage difference dissimilarity measure because it 231 accounts for species abundance, circumvents the double-absence problem (Legendre and 232 Gallagher 2001) and is recommended for testing biotic homogenization (Olden and Rooney 233 2006). The square root of dissimilarities was calculated to obtain Euclidean matrices. 234 Normality and homogeneity of variance assumptions were reached after transformation. To 235 test the effect of site minerotrophy and deer browsing levels on alpha and beta diversity 236 analyses, we used a linear mixed model with browsing and $\mathrm{pH}$ levels as a fixed factor and 237 sites as a random factor.

$238 \quad$ PRC as well as richness, alpha and beta diversity analyses were performed in R (R Core 239 Team 2016), using respectively prc, specnumber, diversity and betadisper in the vegan 240 package (Oksanen et al. 2016). Linear mixed model analyses were performed using the 241 nlme package (Pinheiro et al. 2016) and k-means cluster analyses using the kmeans 242 function of the stats package (R Core Team 2016). Statistical analyses of structure (strata 243 cover and herb height) were performed using the MIXED procedure in SAS software (SAS 244 Institute Inc. 2012).

\section{$245 \quad$ Results}

\section{Changes in vegetation composition over time}

247 Vascular species composition of exclosures diverged from that of unprotected plots 248 through time, but only in shrub fens and laggs (Fig. 1). Changes in composition of 249 exclosures in these two habitats were pronounced soon after deer exclusion, slowed down 250 for two years and then intensified again during the last three years of the survey. Yet, only 251 after eight years of deer exclusion did composition differ significantly between unprotected 252 plots and exclosures (Fig. 1). The exclusion of deer did not change bryophyte composition 253 of peatlands, as no significant difference between exclosures and unprotected plots was 
254 found at any time in any habitat (Table S2; Fig. S1). The succession in exclosures of shrub 255 fens and laggs was attributed to seven species that benefitted from deer exclusion (positive 256 scores on the right vertical axis), among them Sanguisorba canadensis L. and Betula 257 pumila L. On the other hand, five to seven species including Dasiphora fruticosa (L.) 258 Rydberg, Trichophorum cespitosum (L.) Hartman, Carex flava L. and C. aquatilis 259 Wahlenberg were associated with browsing in shrub fens and laggs.

260 Vegetation structure

261 The exclusion of deer promoted shrub expansion equally in all habitats (habitat-deer 262 interaction: $F_{[3,49]}=0.08, p=0.97$ ) and the effect intensified with time (deer-year 263 interaction: $\left.F_{[3,286]}=3.22, p=0.02\right)($ Fig. 2; see complete results in Table S3). Mean shrub 264 cover was about $30 \%$ higher in exclosures than in unprotected plots after both five $\left(F_{[1,286]}\right.$ $265=8.4, p=0.004)$ and eight years $\left(F_{[1,286]}=12.1, p=0.0006\right)$. Herbaceous cover responded 266 to deer exclusion only in laggs, where their cover was $43 \%$ greater in exclosures than in 267 unprotected plots (Fig. 3; $F_{[1,49]}=34.65, p=<0.0001$ ), and the impact of deer exclusion 268 seemed to increase with time, although this trend was not significant (deer-time interaction $269 F_{[3,294]}=2.15, p=0.09$; Table S4). Regarding height, the 12 herbaceous species measured 270 in 2015 were $70 \%$ taller in exclosures (mean $32 \mathrm{~cm}$ ) than in unprotected plots (mean 19 $271 \mathrm{~cm}$ ) of laggs (Fig. 4; $F_{[1,39]}=37.5, p<0.0001$ ), and there was a similar tendency in shrub 272 fens $\left(F_{[1,39]}=3.2, p=0.08\right.$; Fig. 4; Table S5). Furthermore, we observed that two of the 273 herbaceous species flowered only in exclosures: Sanguisorba canadensis (2 flowers) and 274 Thalictrum pubescens Pursh (16 flowers).

275 Alpha and beta diversity

276 Although species richness increased with site minerotrophy $\left(F_{[3,49]}=24.81, p<0.0001\right)$, 277 there was no effect of deer browsing $\left(F_{[1,49]}=1.15, p=0.11\right.$; Table S6). On the other hand, 
278 deer impacted alpha diversity (Shannon index), but this varied according to site 279 minerotrophy ( $\mathrm{pH}$-deer interaction; $F_{[3,49]}=3.00, p=0.04$; Table $\mathrm{S} 7$ ). More precisely, there 280 was a significant increase in alpha diversity following deer exclusion in low moderate rich 281 sites ( $\mathrm{pH}$ of 5.3 to $6.3 ; F=5.43, p=0.02$; Fig. 5 ) and high moderate rich sites ( $\mathrm{pH}$ of 6.3 to 282 $6.8 ; F=9.24, p=0.004)$. Beta diversity followed a unimodal hump-shaped relationship 283 with minerotrophy for both exclosures (quadratic contrast, $p=0.0004$ ) and unprotected 284 plots $(p=0.002)$ and was highest at high moderate rich sites ( $\mathrm{pH}$ of 6.3 to 6.8; Fig. 5). Beta 285 diversity was higher in exclosures than in unprotected plots on more minerotrophic sites $286(\mathrm{pH}>6.3)$, eight years after initiation of deer exclusion $(F=7.29, p=0.01 ; \mathrm{F}=15.37$, $287 \quad p=0.0003$; Fig. 5, Table S8).

\section{Discussion}

\section{Changes in vegetation composition over time}

As predicted, the response of peatlands to deer exclusion was strongly linked to site 291 minerotrophy: only shrub fens and laggs showed divergent plant communities between 292 exclosures and unprotected plots, after eight years of deer exclusion. The lack of response 293 of sedge fens is likely due to the abundance of graminoid plants. Although graminoids can 294 compose more than 50\% of while-tailed deer diet in early spring (Huot 1982), they are 295 particularly tolerant to herbivory because of their capacity for compensatory growth 296 through basal intercalary meristems (Haukioja and Koricheva 2000). Under high herbivory 297 pressure, graminoids can, however, prevent plant community recovery after deer exclusion 298 and even be associated with alternative successional trajectories (Hidding et al. 2013). In 299 bogs, the absence of vegetation change through time could be related to less herbivory 300 pressure, because plants in nutrient-poor environments usually contain more defence 301 compounds than those in nutrient-rich environments (Bryant et al. 1983; Koricheva et al. 
302 303 304 305 306 307 308 309 310 311 312 313

1998). In the context of high deer density, however, deer have been shown to browse even species they usually avoid (Pellerin et al. 2006; Lefort et al. 2007): high rates of browsing have been measured on ericaceous species of Anticosti (78\% for Chamaedaphne calyculata (L.) Moench, 48\% for Kalmia angustifolia L., 47\% for Kalmia polifolia Wangenheim, 43\% for Andromeda glaucophylla Link, 35\% for Rhododendron groenlandicum (Oeder) Kron and Judd; Pellerin et al. 2006). On the other hand, plants in bogs could be less tolerant to herbivory than plants in fens due to lower nutrient availability and associated reduced recovery abilities (Maschinski and Whitham 1989; Wise and Abrahamson 2005); as well, more than eight years may be necessary to detect any recovery from herbivory in bogs. Direct browsing measurements in bogs and sedge fens would nevertheless make it possible to clarify whether the lack of response after deer exclusion is rather associated with a low initial rate of plant consumption or slow recovery after browsing.

No response was observed in bryophytes after deer exclusion. Trampling by large herbivores in peatlands has previously been shown to induce changes in bryophyte diversity and cover, especially in the wettest portions of peatlands, due to the destruction of plants and compaction or sinking of living mosses in the peat deposit (e.g., Pellerin et al. 2006; Groome and Shaw 2015), Sphagnum mosses being particularly sensitive to trampling (e.g., Studlar 1980; Arnesen 1999). However, the impacts of herbivores on bryophytes are usually limited to tracks, whereas these were avoided when setting up exclosures and paired unprotected plots.

Although the use of PRC for assessing changes in plant communities following restoration is only emerging (Poulin et al. 2013), this technique made it possible to identify the main species responsible for the observed changes in shrub fens and laggs with a clear 
statistical evaluation of each species' contribution. In shrub fens, the changes in plant

326

327

328

329

330

331

332

333

334

335

336

337

338

339

340

341

342

343

344

345

346

347 348

communities after deer exclusion were driven by palatable species such as Sanguisorba

canadensis L. and Betula pumila L. The former is a highly palatable forb found in calcareous fens (Bergerud 1972). Its flowers were observed in two exclosures, in 2012 and 2015. Similar observations were reported in Shenandoah National Park (USA), where this species was found to have a greater cover and 33\% more flowering plants in deer exclosures than in controls in a fen after two years (National Park Service 2010). As for Betula pumila, a deciduous shrub highly palatable for large herbivores (Bergerud 1972), its total leaf area has been previously shown to be six times smaller on Anticosti Island than on the nearby deer-free Mingan Archipelago (Pellerin et al. 2006). Among the species characterizing unprotected plots of shrub fens and laggs, Dasiphora fruticosa is a shrub resistant to herbivores (Lovaas 1958; Elkington and Woodell 1963) but known to be highly browsed on Anticosti Island (Pellerin et al. 2006), likely due to the scarcity of other resources, as suggested by Elkington and Woodell (1963). Five graminoid species remained associated with browsing in both shrub fens and laggs, reinforcing comments above concerning the high ability of these plants to persist in browsed environments (Stockton et al. 2005; Rooney 2009; Bachand et al. 2015).

\section{Vegetation structure}

Shrub cover responded positively to deer exclusion, regardless of habitat type. Contrary to our prediction, this reveals that browsing on shrubs occurred in all habitats and that minerotrophy did not influence the capacity of shrubs to respond after deer exclusion. Similarly, shrub cover expansion (Middleton 2002; Middleton et al. 2006) and densification (McShea et al. 2000) or shoot elongation (Johnson and Leopold 1998) following deer exclusion have been previously observed in some peatlands, while other studies found no 
349 change when comparing regions with or without deer browsing history (Pellerin et al. 350 2006). On the other hand, we found that herbs benefitted only in laggs where there was an 351 increase in both their cover and height after deer exclusion. Prior to exclusion, laggs not 352 only showed the highest cover of herbs compared to other habitats; but also higher mineral 353 and nutrient contents, due in part to runoff from adjacent mineral soils, which could have 354 fostered herb recovery (Paradis et al. 2015). The peat deposit was also thinner in laggs 355 (mean $75 \mathrm{~cm}$ ) than in other peatland types (mean $174 \mathrm{~cm}$ ), which could have favored root 356 access to the underlying mineral soil layer (Glaser et al. 1990) and thus herbaceous growth 357 when deer browsing was suppressed. Alternatively, deer browsing could be more important 358 in laggs because the high nutrient availability usually generates high nutritional quality, as 359 suggested by the carbon-nutrient balance hypothesis (Bryant et al. 1983; Koricheva et al. 360 1998). Again, direct measurements of browsed vegetation and direct analyses of plant 361 quality would be required to validate either hypothesis. The lack of response of bryophytes 362 in all habitats could be attributed to low recovery ability or to low browsing, as for herbs in 363 bogs and fens, but could also be attributed to the fact that their cover was difficult to 364 evaluate. We suspect that the main effect of year $\left(F_{[3,290]}=3.78, p=0.01\right)$ was intimately 365 linked with the capacity of observers to distinguish moss carpets from bare peat, especially 366 under standing water.

\section{Alpha and beta diversity}

368 Although species richness was not influenced by deer exclusion, we showed that both 369 alpha and beta diversity increased after deer exclusion, but only on more minerotrophic 370 sites. Studies investigating the impact of herbivores on species diversity of peatlands have 371 mostly considered grazing livestock on managed sites. Grazing suppression in calcareous 372 fens of Wisconsin (USA) raised species richness for four years, after which richness 
373

374 375

converged toward that found on heavily and lightly browsed sites (Middleton 2002); fens that had never been grazed were even poorer in species. In contrast, species richness was reduced by grazing in managed calcareous fens in Germany (Stammel et al. 2003).

In regard to beta diversity, many studies have revealed that large herbivores can induce biotic homogenization in forests (Rooney 2009; Holmes and Webster 2011) and in shrublands (Perea et al. 2014), but to our knowledge, no study has assessed their impact on plant diversity in relation to site minerotrophy. The increase in herbaceous production along this gradient may have contributed to the increase in beta diversity after deer exclusion on our study sites (Maschinski and Whitham 1989; Wise and Abrahamson 2005). Yet, in other ecosystems such as prairies and rangelands, large herbivores have been shown to have a positive impact on plant diversity at high plant productivity (Osem et al. 2002; Frank 2005; Bakker et al. 2006), potentially by limiting competition for light through biomass removal. This is less likely to occur in stressful environments, such as waterlogged peatlands, for which facilitation interactions have been shown to be more important than competition (Bertness and Callaway 1994; Calaway 2007; Maestre et al. 2009). The increase in beta diversity after deer exclusion on more minerotrophic sites in our study may therefore rather be associated with the variability of site conditions. Indeed, rich fens and laggs are highly influenced by water seepage from surrounding landscapes, whereas bogs are fed by atmospheric water supply alone (Wieder and Vitt 2006). Deer exclusion can therefore allow the establishment of a more diverse herbaceous flora in richer peatlands than in bogs, simply because recolonizing species will be adapted to local conditions, which vary among sites. Under browsing pressure, these species could indeed persist in the seed bank and help regenerate plant communities after deer exclusion, as a high proportion 
396 of herb species of standing vegetation has been associated with the seed bank in fens in 397 particular (Valkó et al. 2011).

398

\section{Conclusion}

Our study showed that herbivores can impoverish the flora of peatlands both locally and regionally, but that richer sites are resilient to browsing. Discrepancies between exclosures and unprotected plots were indeed more important in shrub fens and laggs than in bogs and sedge fens. Bogs may be resistant to browsing because they harbor few palatable species, while sedge fens may be resilient to browsing due to high compensatory growth of graminoids under the continuous presence of herbivores. These peatland habitats may also have a lower resilience when deer are excluded due to a slow response of plant communities, but studies with a longer time-frame will be needed to evaluate this aspect. Richness and diversity results also suggest that conservation efforts in regions with overabundant large herbivores should focus on richer peatland habitats to promote alpha and beta diversity. Although our study was conducted in a boreal region where white-tailed deer are usually not overabundant, we believe our results could also apply to temperate regions where peatlands are abundant and situated close to forests exposed to high deer densities. For example, deer populations are high in the St. Lawrence lowlands (Huot and Lebel 2012) where peatlands still cover as much as 10\% of the area (Poulin et al. 2016) and are surrounded by mixed or deciduous forests. Newfoundland (Canada), also hosts similar contexts where forests and peatlands co-occur and cervid densities are high (Gosse et al. 2011). Finally, our study improves our understanding of the influence of minerotrophy on the capacity of ecosystems to respond to disturbances. Peatlands are indeed valuable model 
418 ecosystems in this regard, as their $\mathrm{pH}$ can vary from 3.6 to 7 within a single region and

419 allow comparison of browsing treatments over a range of minerotrophy.

\section{$420 \quad$ Acknowledgements}

421 Funding was provided by the Natural Sciences and Engineering Research Council of

422 Canada (NSERC) Industrial Chair to SDC, the Ministère des Ressources Naturelles et de la

423 Faune du Québec, the Canadian Forest Service of Natural Resources Canada, and NSERC

424 and FRQNT scholarships to MC, and NSERC DGs to MP and SP. We are grateful to the

425 Centre de la Science de la Biodiversité du Québec and Centre d'études nordiques for

426 scholarships. Our thanks also to G. Ayotte, S. Ménard and A. Benoist-Chénier for their

427 pivotal role in establishing and maintaining the deer exclusion experiment. Thanks to $\mathrm{P}$.

428 Legendre and G. Daigle for useful advice on statistical issues, to K. Grislis for linguistic

429 revision and to the numerous field assistants throughout the years.

430 


\section{References}

Alday, J.G., and Marrs, R.H. 2014. A simple test for alternative states in ecological restoration: the use of principal response curves. Appl. Veg. Sci. 17: 302-311. doi:10.1111/avsc. 12054

Anderson, M.J., Ellingsen, K.E., and McArdle, B.H. 2006. Multivariate dispersion as a measure of beta diversity. Ecol. Lett. 9: 683-693. doi:10.1111/j.14610248.2006.00926.x

Arnesen, T. 1999. Vegetation dynamics following trampling in rich fen at Sølendet, Central Norway; a 15 year study of recovery. Nord. J. Bot. 19: 313-327. doi:10.1111/j.1756-1051.1999.tb01118.x

Ausden, M., Hall, M., Pearson, P., and Strudwick, T. 2005. The effects of cattle grazing on tall-herb fen vegetation and molluscs. Biol. Conserv. 122: 317-326. doi:10.1016/j.biocon.2004.07.021

Austrheim, G., and Eriksson, O. 2001. Plant species diversity and grazing in the Scandinavian mountains-patterns and processes at different spatial scales. Ecography 24: 683-695. doi: 10.1111/j.1600-0587.2001.tb00530.x

Bachand, M., Pellerin, S., Tremblay, J.-P., Côté, S.D., and Poulin, M. 2015. Compositional and functional trajectories of herbaceous communities after deer density control in clear-cut boreal forests. Can. J. For. Res. 45: 758-763. doi:10.1139/cjfr-2014-0533

Bakker, E.S., Ritchie, M.E., Olff, H., Milchunas, D.G., and Knops, J.M. 2006. Herbivore impact on grassland plant diversity depends on habitat productivity and herbivore size. Ecol. Lett. 9: 780-788. doi:10.1111/j.1461-0248.2006.00925.x 
454 455

456

457 458

459

460

461

462

463

464 465

Barrette, M., Belanger, L., and De Grandpre, L. 2010. Preindustrial reconstruction of a perhumid midboreal landscape, Anticosti Island, Quebec. Can. J. For. Res. 40: 928-942. doi:10.1139/X10-040

Beguin J., Pothier, D., and Côté, S.D. 2011. Deer browsing and soil disturbance induce cascading effects on plant communities: a multilevel path analysis. Ecol. Appl. 21: 439-451. doi:10.1890/09-2100.1

Bergerud, A.T. 1972. Food habits of newfoundland Caribou. J. Wildl. Manage. 36: 913923. doi: $10.2307 / 3799448$

Bertness, M.D., and Callaway, R.M. 1994. Positive interactions in communities. Trends Ecol. Evol. 9: 191-193. doi:10.1016/0169-5347(94)90088-4

Birnie, R.V., and Hulme, P.D. 1990. Overgrazing of peatland vegetation in shetland. Scot. Geogr. Mag. 106: 28-36. doi:10.1080/00369229018736772

Bryant, J.P., Chapin, F.S. and Klein, D.R. 1983. Carbon nutrient balance of boreal plants in relation to vertebrate herbivory. Oikos, 40: 357-368. doi: 10.2307/3544308

Callaway, R.M. 2007. Positive Interactions and interdependence in plant communities. Springer, Dordrecht. doi: 10.1007/978-1-4020-6224-7

Côté, S.D., Rooney, T.P., Tremblay, J.-P., Dussault, C., and Waller, D.M. 2004. Ecological impacts of deer overabundance. Annu. Rev. Ecol. Evol. Syst. 35: 113147. doi:10.1146/annurev.ecolsys.35.021103.105725

Downing, A.S., van Nes, E.H., Mooij, W.M., and Scheffer, M. 2012. The resilience and resistance of an ecosystem to a collapse of diversity. PLoS ONE, 7: e46135. doi.org/10.1371/journal.pone.0046135 
476 Elkington, T.T., and Woodell, S.R.J. 1963. Potentilla fruticosa L. J. Ecol. 51: 769-781.

477

478

479

480

481

482

483

484

485

486

487

488

489

490

491

492

493

494

495

496

497

doi: $10.2307 / 2257763$

Environment Canada. 2006. Canadian climate cormals, Port-Menier meteorological station [online]. Available from http://www.climate.weatheroffice.ec.gc.ca [accessed 8 June 2006].

Folke, C., Carpenter, S., Walker, B., Scheffer, M., Elmqvist, T., Gunderson, L. and Holling, C.S. 2004. Regime shifts, resilience, and biodiversity in ecosystem management. Annu. Rev. Ecol. Evol. Syst 35: 557-581. doi:10.1146/annurev.ecolsys.35.021103.105711

Frank, D.A. 2005. The interactive effects of grazing ungulates and aboveground production on grassland diversity. Oecologia, 143: 629-634. doi:10.1007/s00442005-0019-2

Gering, J.C., Crist, T.O., and Veech, J.A. 2003. Additive partitioning of species diversity across multiple spatial scales: implications for regional conservation of biodiversity. Conserv. Biol. 17: 488-499. doi:10.1046/j.1523-1739.2003.01465.x

Glaser, P.H., Janssens, J.A., and Siegel, D.I. 1990. The response of vegetation to chemical and hydrological gradients in the Lost River peatland, northern Minnesota. J. Ecol. 78: 1021-1048. doi:10.2307/2260950

Goetsch, C., Wigg, J., Royo, A.A., Ristau, T., and Carson, W.P. 2011. Chronic over browsing and biodiversity collapse in a forest understory in Pennsylvania: results from a 60 year-old deer exclusion plot. J. Torrey Bot. Soc. 138: 220-224. doi:10.3159/TORREY-D-11-00013.1 
498 499

500

501

502

503

504

505 506

Gosse, J., Hermanutz, L., McLaren, B., Deering, P., and Knight, T. 2011. Degradation of boreal forests by non-native herbivores in Newfoundland's National Parks: recommendations for ecosystem restoration. Nat. Areas J. 31: 331-339. doi:10.3375/043.031.0403.

Groom, G., and Shaw, P. 2015. Vegetation response to the reintroduction of cattle grazing on an English lowland valley mire and wet heath. Conservation Evidence 12: 33-39.

Haukioja, E., and Koricheva, J. 2000. Tolerance to herbivory in woody vs. herbaceous plants. Evol. Ecol. 14: 551-562. doi:10.1023/A:1011091606022

Hidding, B., Tremblay, J.-P. and Côté, S.D. 2013. A large herbivore triggers alternative successional trajectories in the boreal forest. Ecology, 94: 2852-2860. doi:10.1890/12-2015.1

Hofmann, R.R. 1989. Evolutionary steps of ecophysiological adaptation and diversification of ruminants: a comparative view of their digestive system. Oecologia, 78: 443-457. doi:10.1007/BF00378733.

Holmes, S.A., and Webster, C.R. 2011. Herbivore-induced expansion of generalist species as a driver of homogenization in post-disturbance plant communities. Plant Ecol. 212: 753-768. doi:10.1007/s11258-010-9858-y

Howie, S.A., and Tromp-van Meerveld, I. 2011. The essential role of the lagg in raised bog function and restoration: a review. Wetlands, 31: 613-622. doi:10.1007/s13157-011-0168-5.

Huot, J. 1982. Body condition and food resources of white-tailed deer on Anticosti island, Quebec. Ph.D. thesis, University of Alaska, Fairbanks, Alaska, USA. 
521

522

523

524

525

526

527

528

529

530

531

532

533

Huot, M., and Lebel, F. 2012. Plan de gestion du cerf de Virginie au Québec 2010-2017, ministère des Ressources naturelles et de la Faune — Secteur Faune Québec, Direction générale de l'expertise sur la faune et ses habitats, 578 p.

Johnson, A.M., and Leopold, D.J. 1994. Vascular plant species richness and rarity across a minerotrophic gradient in wetlands of St. Lawrence County, New York, USA. Biodivers. Conserv. 3: 606-627. doi:10.1007/BF00114204

Johnson, G., and Leopold, D.J. 1998. Habitat management for the eastern Massasauga in a central New York peatland. J. Wildl. Manage. 62: 84-97. doi:10.2307/3802266

Koricheva, J., Larsson, S., Haukioja, E. and Keinänen, M. 1998. Regulation of woody plant secondary metabolism by resource availability: hypothesis testing by means of meta-analysis. Oikos, 83: 212-226. doi:10.2307/3546833

Lavoie, M., and Fillion, L. 2001. Holocene vegetation dynamics of Anticosti Island, Québec, and consequences of remoteness on ecological succession. Quaternary Res. 56: 112-127. doi:10.1006/qres.2001.2239

Lefort, S., Tremblay, J.-P., Fournier, F., Potvin, F., and Huot, J. 2007. Importance of balsam fir as winter forage for white-tailed deer at the northeastern limit of their distribution range. Ecoscience, 14: 109-116. doi:10.2980/11956860(2007)14[109:IOBFAW]2.0.CO;2

Legendre, P., and Gallagher, E.D. 2001. Ecologically meaningful transformations for ordination of species data. Oecologia, 129: 271-280. doi:10.1007/s004420100716 Locky, D.A., and Bayley, S.E. 2006. Plant diversity, composition, and rarity in the southern boreal peatlands of Manitoba, Canada. Can. J. Bot. 84: 940-955. doi:10.1139/b06-049 
544 Lovaas, A.L. 1958. Mule deer food habits and range use, Little Belt Mountains, Montana.

545

546

547

548

549

550

551

552

553

554

555

556

557

558

559

560

561

562

563

564

565

J. Wildl. Manage. 22: 275-283. doi:10.2307/3796460

Maestre, F.T., Callaway, R.M., Valladares, F. and Lortie, C.J. 2009. Refining the stressgradient hypothesis for competition and facilitation in plant communities. J. Ecol. 97: 199-205. doi:10.1111/j.1365-2745.2008.01476.x

Maschinski, J., and Whitham, T.G. 1989. The continuum of plant responses to herbivory: the influence of plant association, nutrient availability, and timing. Am. Nat. 134: 1-19. doi:10.1086/284962

Massé, A., and Côté, S.D. 2009. Habitat selection of a large herbivore at high density and without predation: Trade-off between forage and cover? J. Mammal. 90: 961-970. doi:10.1644/08-MAMM-A-148.1

Mattson, W.J. 1980. Herbivory in relation to plant nitrogen content. Annu. Rev. Ecol. Syst. 11: 119-161. doi:10.1146/annurev.es.11.110180.001003

Mayer, R., Kaufmann, R., Vorhausen, K., and Erschbamer, B. 2009. Effects of grazing exclusion on species composition in high-altitude grasslands of the Central Alps. Basic Appl. Ecol. 10: 447-455. doi:10.1016/j.baae.2008.10.004

McKinney, M.L., and Lockwood, J.L. 1999. Biotic homogenization: a few winners replacing many losers in the next mass extinction. Trends Ecol. Evol. 14: 450453. doi:10.1016/S0169-5347(99)01679-1

McShea, W.J., and Rappole, J.H. 2000. Managing the abundance and diversity of breeding bird populations through manipulation of deer populations. Conserv. Biol. 14: 1161-1170. doi:10.1046/j.1523-1739.2000.99210.x 
566 Middleton, B. 2002. Winter burning and the reduction of Cornus sericea in sedge 567 meadows in southern Wisconsin. Restor. Ecol. 10: 723-730. doi:10.1046/j.1526100X.2002.01053.X

569 570 571 572 573 574 575 576 577 578 579 580 581 582

Middleton, B.A., Holsten, B., and van Diggelen, R. 2006. Biodiversity management of fens and fen meadows by grazing, cutting and burning. Appl. Veg. Sci. 9: 3073016. doi:10.1111/j.1654-109X.2006.tb00680.x

Moore, T.R., Bubier, J.L., Frolking, S.E., Lafleur, P.M., and Roulet, N.T. 2002. Plant biomass and production and $\mathrm{CO}_{2}$ exchange in an ombrotrophic bog. J. Ecol. 90: 25-36. doi:10.1046/j.0022-0477.2001.00633.x

National Park Service. 2010. Deer exclosures. US Department of the Interior, Shenandoah National Park. Washington D.C.

Oksanen, J., Blanchet, F.G., Kindt, R., Legendre, P., Minchin, P.R., O’Hara, R.B., Simpson, G.L., Solymos, P., Stevens, M.H.H., and Wagner, H. 2016. Vegan: Community ecology package. $\mathrm{R}$ package version 2.3-3.

Olden, J.D., Poff, N.L., Douglas, M.R., Douglas, M.E., and Fausch, K.D. 2004. Ecological and evolutionary consequences of biotic homogenization. Trends Ecol. Evol. 19: 18-24. doi:10.1016/j.tree.2003.09.010

Olden, J.D., and Rooney, T.P. 2006. On defining and quantifying biotic homogenization. Global Ecol. Biogeogr. 15: 113-120. doi:10.1111/j.1466-822X.2006.00214.X

Ohashi, H. and Hoshino, Y. 2014. Disturbance by large herbivores alters the relative importance of the ecological processes that influence the assembly pattern in heterogeneous meta-communities. Ecol. Evol. 4: 766-775. doi:10.1002/ece3.987 
588 Osem, Y., Perevolotsky, A., and Kigel, J. 2002. Grazing effect on diversity of annual

589

590

591

592

593

594

595

596

597

598

599

600

601

602

603

604

605

606

607

608

plant communities in a semi-arid rangeland: interactions with small-scale spatial and temporal variation in primary productivity. J. Ecol. 90: 936-946. doi:10.1046/j.1365-2745.2002.00730.x

Paradis, É., Rochefort, L., and Langlois, M. 2015. The lagg ecotone: an integrative part of bog ecosystems in North America. Plant Ecol. 216: 999-1018. doi:10.1007/s11258-015-0485-5

Pellerin, S., Huot, J., and Côté, S.D. 2006. Long-term effects of deer browsing and trampling on the vegetation of peatlands. Biol. Conserv. 128: 316-326. doi:10.1016/j.biocon.2005.09.039

Perea, R., Girardello, M., and San Miguel, A. 2014. Big game or big loss? High deer densities are threatening woody plant diversity and vegetation dynamics. Biodivers. Conserv. 23: 1303-1318. doi:10.1007/s10531-014-0666-X

Peterson, G., Allen, C.R., and Holling, C.S. 1998. Ecological Resilience, Biodiversity, and Scale. Ecosystems 1: 6-18. doi:10.1007/s100219900002

Pinheiro, J., Bates, D., Debroy, S., Sarkar, D., and Team R. Core, 2016. nlme: Linear and nonlinear mixed effects models [Online]. Available: http://CRAN.Rproject.org $/$ package $=$ nlme

Potvin, F., Beaupré, P., and Laprise, G. 2003. The eradication of balsam fir stands by white-tailed deer on Anticosti Island, Quebec: A 150-year process. Ecoscience, 10: 487-495. doi:10.1080/11956860.2003.11682796 
609 Poulin, M., Anderson, R., and Rochefort, L. 2013. A New approach for tracking 610 vegetation change after Restoration: A case study with peatlands. Restor. Ecol.

612 Poulin, M. and Pellerin, S., Cimon-Morin, J., Lavallée, S., Courchesne, G., and Tendland, 613 Y. 2016. Inefficacy of wetland legislation for conserving Quebec wetlands as revealed by mapping of recent disturbances. Wetlands Ecol. Manage. 24: 651665. doi:10.1007/s11273-016-9494-y

Rawes, M. 1983. Changes in two high altitude blanket bogs after the cessation of sheep grazing. J. Ecol. 71: 219-235. doi:10.2307/2259974

Rawes, M., and Hobbs, R. 1979. Management of semi-natural blanket bog in the northern Pennines. J. Ecol. 67: 789-807. doi:10.2307/2259215

R Core Team 2016. R: A language and environment for statistical computing. R foundation for statistical computing, Vienna, Austria. [online]. Available from https://www.R-project.Org/

Rochette, B., and Gingras, A. 2007. Inventaire aérien du cerf de virginie de l'île d'anticosti- été 2006. Société de la faune et des parcs du Québec, Direction de l'aménagement de la faune de la Côte-Nord et Direction de la recherche sur la faune, Québec. 19 p.

Rooney, T. 2009. High white-tailed deer densities benefit graminoids and contribute to biotic homogenization of forest ground-layer vegetation. Plant Ecol. 202: 103111. doi: $10.1007 / \mathrm{s} 11258-008-9489-8$ 
Rooney, T.P., and Waller, D.M. 2003. Direct and indirect effects of white-tailed deer in forest ecosystems. For. Ecol. Manage. 181: 165-176. doi:10.1016/S0378$1127(03) 00130-0$

Rooney, T.P., Wiegmann, S.M., Rogers, D.A., and Waller, D.M. 2004. Biotic impoverishment and homogenization in unfragmented forest understory communities. Conserv. Biol. 18: 787-798. doi:10.1111/j.1523-1739.2004.00515.x SAS Institute. 2012. SAS for Windows V9.4. NC: SAS Institute.

Saucier, J.-P., Grondin, P., Robitaille, A., Gosselin, J., Morneau, C., Richard, P.J.H., Brisson, J., Sirois, L., Leduc, A., Morin, H., Thiffault, É., Gauthier, S., Lavoie, C. and Payette, S. 2009. Écologie forestière, in Manuel de foresterie. Edited by Ordre des Ingénieurs forestiers du Québec, 2éd. Ouvrage collectif, Éditions MultiMondes, Québec, p.165-316.

Schumacher, H.B., and Carson, W.P. 2013. Biotic homogenization of the sapling layer in 19 late-successional and old-growth forest stands in Pennsylvania. J. Torrey Bot. Soc. 140: 313-328. doi:10.3159/TORREY-D-11-00002.1

Shannon, C.E., and Weaver, W. 1963. The mathematical theory of communication, ÉtatsUnis, University of Illinois Press, Champaign. 144 p. doi:10.1086/398349

Smith, R.S., Charman, D., Rushton, S.P., Sanderson, R.A., Simkin, J.M., and Shiel, R.S. 2003. Vegetation change in an ombrotrophic mire in northern England after excluding sheep. Appl. Veg. Sci. 6: 261-270. doi:10.1111/j.1654109X.2003.tb00587.x

Sokal, R.R., and Rohlf, F.J. 1995. Biometry: The principals and practice of statistics in biological research. W.H. Freeman, New York. doi: 10.2307/2343822 
Speed, J.D.M., Austrheim, G. and Mysterud, A. 2013. The response of plant diversity to grazing varies along an elevational gradient. J. Ecol. 101: 1225-1236 doi:10.1111/1365-2745.12133

Stammel, B., and Kiehl, K. 2004. Do hoof prints actually serve as a regeneration niche for plant species in fens? Phytocoenologia, 34: 271-286. doi:10.1127/0340269X/2004/0034-0271

Stammel, B., Kiehl, K., and Pfadenhauer, J. 2003. Alternative management on fens: Response of vegetation to grazing and mowing. Appl. Veg. Sci. 6: 245-254. doi:10.1111/j.1654-109X.2003.tb00585.x

Stockton, S.A., Allombert, S., Gaston, A.J., and Martin, J.-L. 2005. A natural experiment on the effects of high deer densities on the native flora of coastal temperate rain forests. Biol. Conserv. 126: 118-128. doi:10.1016/j.biocon.2005.06.006

Studlar, S.M. 1980. Trampling effects on bryophytes: trails surveys and experiments. Bryologist, 83: 301-313. doi:10.2307/3242440

Szumigalski, A.R., and Bayley, S.E. 1996. Net above-ground primary production along a bog-rich fen gradient in central Alberta, Canada. Wetlands, 16: 467-476. doi:10.1007/BF03161336

Thormann, M.N., and Bayley, S.E. 1997. Aboveground net priary production along a bog fen marsh gradient in southern boreal Alberta, Canada. Ecoscience, 4: 374-384. doi:10.1080/11956860.1997.11682416

Tremblay, J.-P., Huot, J., and Potvin, F. 2007. Density-related effects of deer browsing on the regeneration dynamics of boreal forests. J. Appl. Ecol. 44: 552-562. doi:10.1111/j.1365-2664.2007.01290.x 
676 Valkó, O., Török, P., Tóthmérész, B., and Matus, G. 2011. Restoration potential in seed

677

678 banks of acidic fen and dry-mesophilous meadows: can restoration be based on local seed banks. Restor. Ecol. 19: 9-15. doi:10.1111/j.1526-100X.2010.00679.x

Van Den Brink, P.J., and Ter Braak, C.J. 1999. Principal response curves: analysis of time-dependent multivariate responses of biological community to stress. Environ. Toxicol. Chem. 18: 138-148. doi:10.1002/etc.5620180207

Vitt, D.H., Bayley, S.E., and Jin, T.-L. 1995. Seasonal variation in water chemistry over a bog-rich fen gradient in continental western Canada. Can. J. Fish. Aquat. Sci. 52: 587-606. doi:10.1139/f95-059

Waller, D. 2014. Effects of deer on forest herb layers. In The herbaceous layer in forests of eastern North America. 2nd Edition. Edited by F.S. Gilliam and M.R. Roberts. Oxford University Press, pp. 369-399.

Ward, S.E., Bardgett, R.D., Mcnamara, N.P., Adamson, J.K., and Ostle, N.J. 2007. Longterm consequences of grazing and burning on northern peatland carbon dynamics. Ecosystems, 10: 1069-1083. doi:10.1007/s10021-007-9080-5

Warner, B.G., and Asada, T. 2006. Biological diversity of peatlands in Canada. Aquat. Sci. 68: 240-253. doi:10.1007/s00027-006-0853-2

Wheeler, B.D. 1993. Botanical diversity in british mires. Biodivers. Conserv. 2: 490-512. doi:10.1007/BF00056744

Wieder, R.K., and Vitt, D.H. (Editors). 2006. Boreal peatland ecosystems, Ecological Studies, Springer-Verlag Berlin Heidelberg, 188, 436 p. . doi:10.1007/978-3-54031913-9 
698 Wise, M.J., and Abrahamson, W.G. 2005. Beyond the compensatory continuum: 699 environmental resource levels and plant tolerance of herbivory. Oikos, 109: 417700 428. doi:10.1111/j.0030-1299.2005.13878.x

701 Zoltai, S., and Vitt, D. 1995. Canadian wetlands: environmental gradients and 702 classification. Vegetatio, 118: 131-137. doi:10.1007/BF00045195

703 


\section{$704 \quad$ Figure captions}

705 Fig.1. Principal response curves representing changes in vascular plant composition 706 between exclosures and unprotected plots by white-tailed deer over time for all types of

707 peatland habitats (Anticosti Island). The proportion of variance explained by the first axis

708 of the PRC is indicated in parentheses. Species on the right-side vertical axis are listed

709 according to their respective score in the PRC, which indicates how each species is

710 correlated with the curves. Only species with a score $>0.2$ are shown. Asterisks indicate

711 significant differences of plant composition between exclosures and unprotected plots

712 (shrub fen: $t=2.8, p=0.01$; lagg: $t=3.6, p=0.001$ ). For a complete list of species for

713 each habitat, see Table S9 to S12.

714

715 Fig. 2. Shrub cover in peatlands (Anticosti Island), all habitats combined. Least squares

716 means $\pm \mathrm{SE}$ of the original data of the interaction between deer and habitats are

717 presented. Significant differences were determined with Fisher's Least mean differences

718 test $(*=p<0.05 ; * *=p<0.01)$.

719

720 Fig. 3. Herbaceous and bryophyte covers in the four types of peatland habitat (Anticosti

721 Island), all years combined. Least squares means $\pm \mathrm{SE}$ of the original data of the

722 interaction between deer and habitats are presented. Significant differences were

723 determined with Fisher's Least mean differences test $(*=p<0.05 ; * *=p<0.01)$. 
726 Fig. 4. Herbaceous plant height in the four types of peatland habitat (Anticosti Island), all 727 years combined. Least squares means $\pm \mathrm{SE}$ of the original data of the interaction between 728 deer and habitats are presented. Significant differences were determined with Fisher's 729 Least mean differences test $\left.*^{*}=p<0.05 ; * *=p<0.01\right)$. See Table S4 for a list of the 12 730 species for which height was measured.

732 Fig. 5. Influence of browsing and minerotrophy (determined using water $\mathrm{pH}$ ) on alpha 733 diversity (Shannon index) and beta diversity in peatlands of Anticosti Island. Beta 734 diversity was measured as the average distance between sites and their group (water $\mathrm{pH}$ ) 735 centroid in exclosures and unprotected plots eight years after deer control. Least squares 736 means \pm SE of the original data of the interaction between deer and group of $\mathrm{pH}$ are 737 presented; comparisons of exclosures and unprotected plots were performed for the four 738 groups of $\mathrm{pH}$. Significant differences were determined by Fisher's Least mean 739 differences test $(* *$ for $P<0.01$ ). 


\section{Fig. 1}
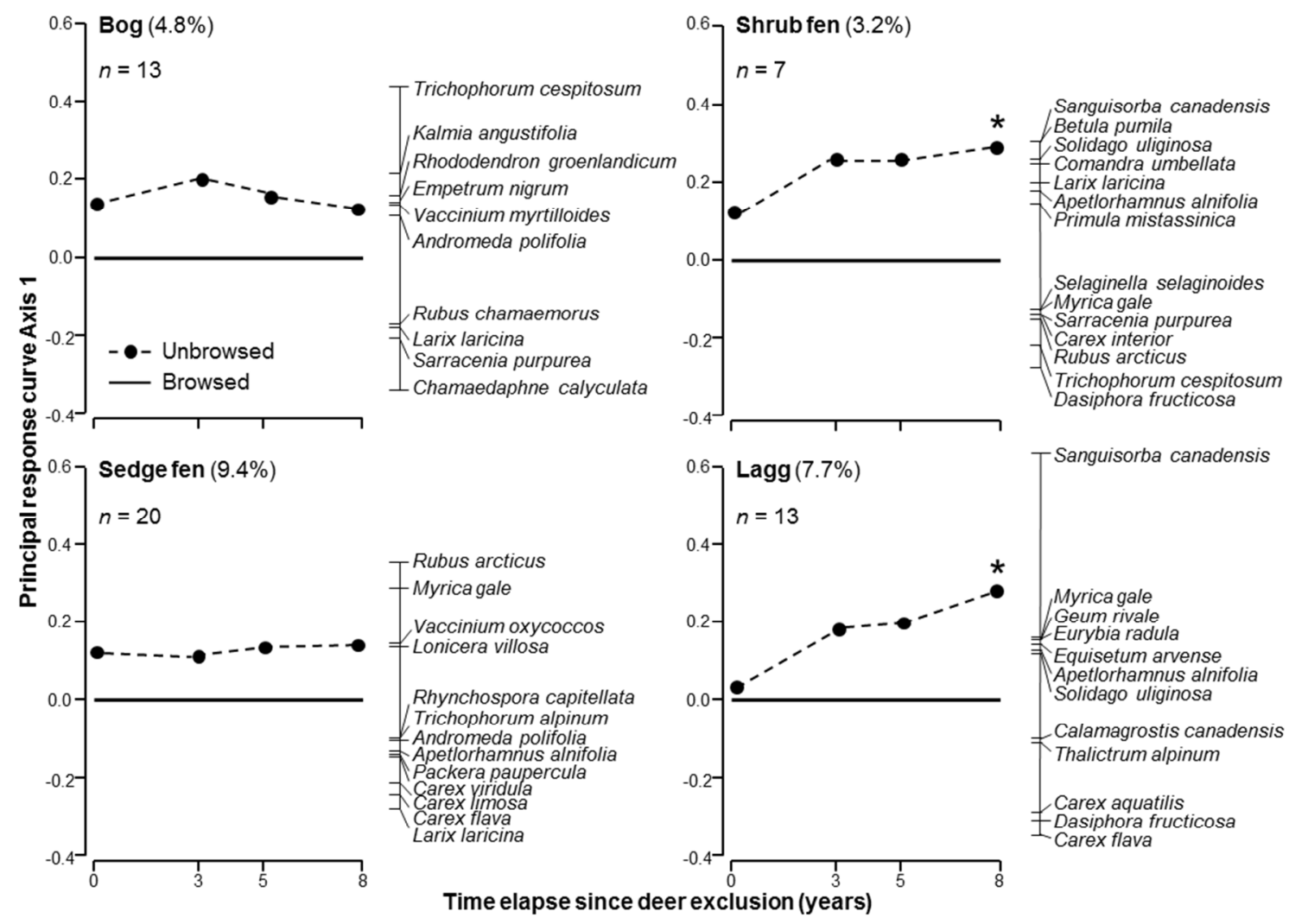
Fig. 2

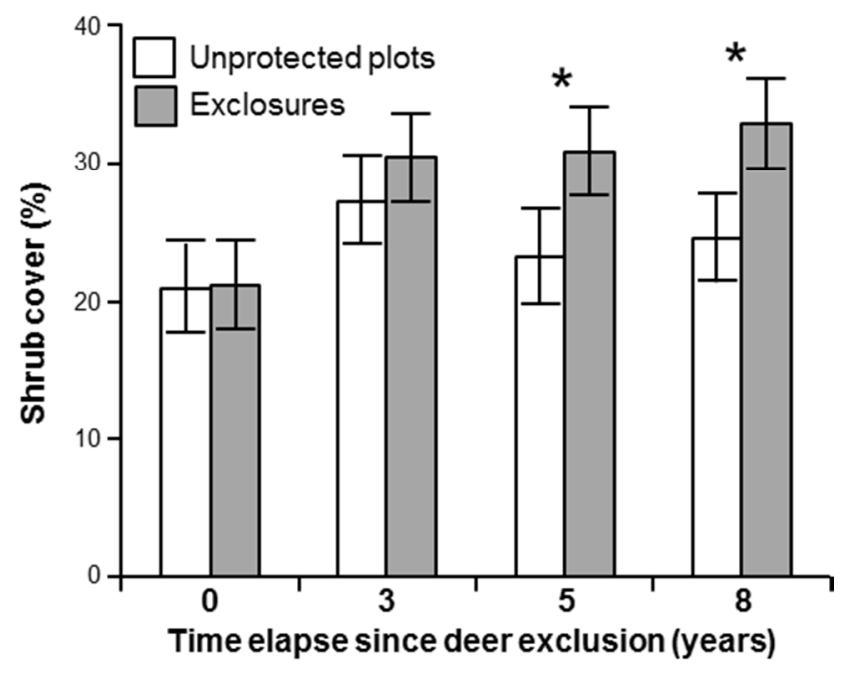


Fig. 3
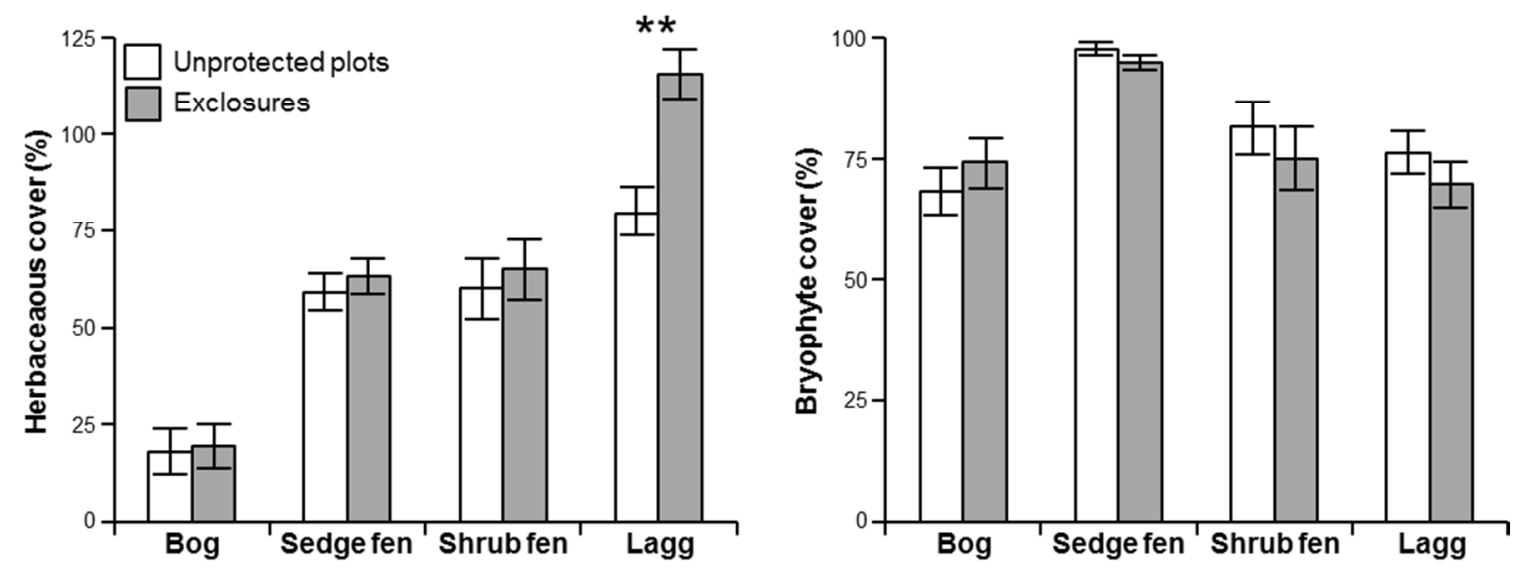
Fig. 4

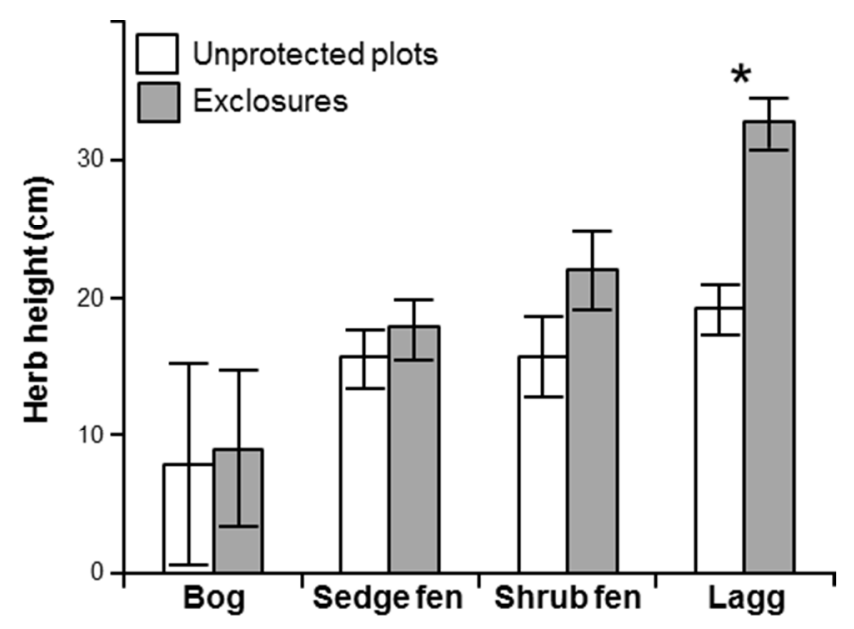


Fig. 5.
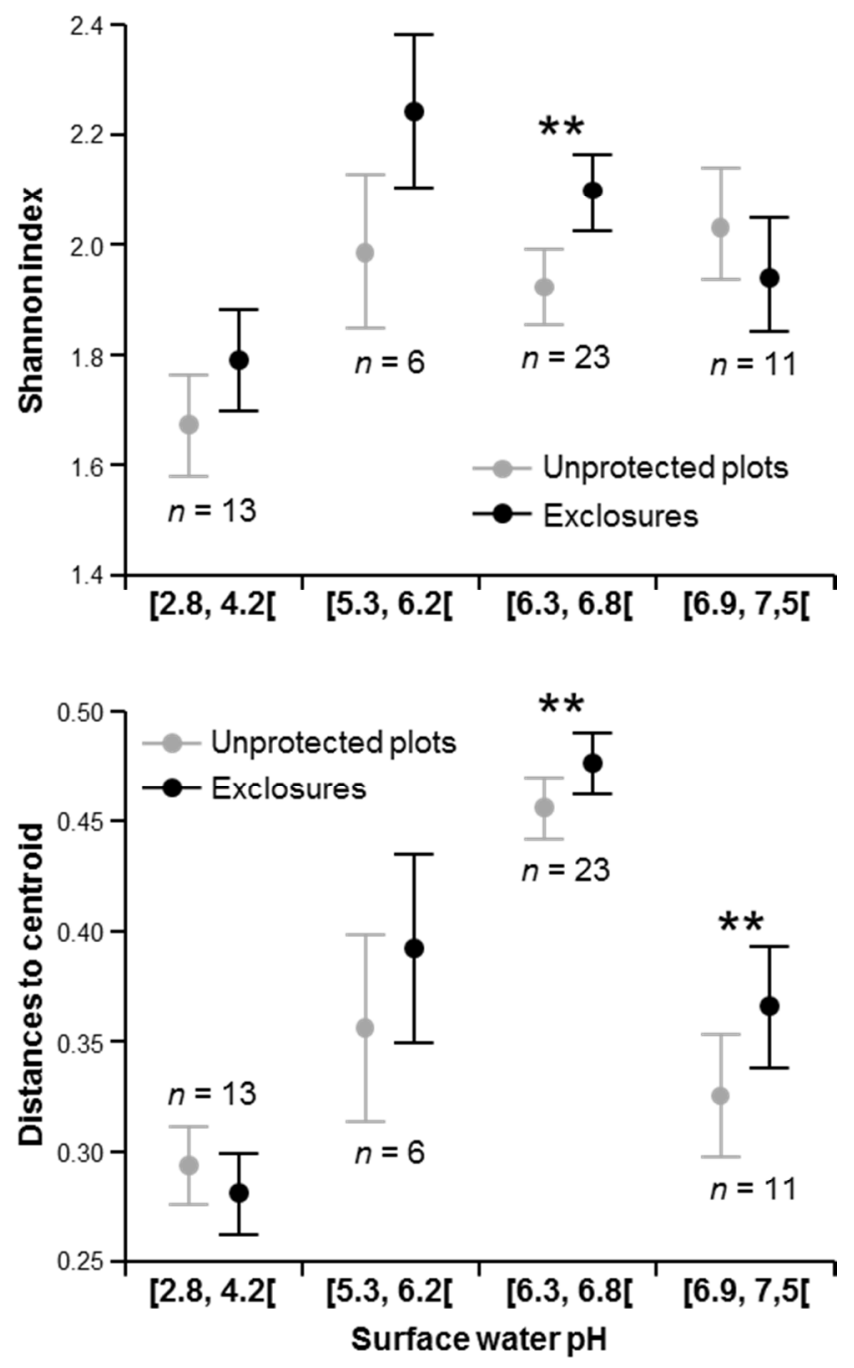